\title{
The Poverty in India-An Over View
}

\author{
Dr. D. Kumuda \\ Associate Professor, Department Of Economics, Bangalore University, P.G .Centre, Kolar
}

\begin{abstract}
India is a country of continental proportions, and poverty is a multidimensional phenomenon. Not surprisingly, the debate over poverty in India-its extent, trends, causes, and cure-is complex and controversial. Fortunately, India also has a much higher quality and more sub-stantial evidence base than most other countries for understanding poverty. Questions of poverty in India have engaged a large com-munity of researchers over the years. But in recent decades, because difficult measurement issues have arisen, a disproportionate amount of attention has been devoted to assessments of the extent of poverty and the rate of poverty decline. Much less is known about how the rapidly changing economic landscape has altered the underlying profile of poverty - and how that affects the consequent search for its causes and cure.

Fundamentally, the concept of poverty is associated with socially perceived deprivation with respect to basic human needs. As a result, social perceptions are taken to play a dominant role in ascertaining deprivation although self-perceptions cannot be ignored altogether and aggregated individual preferences may have to be respected in satisfying any given need in most cases as weargue below in the context of consumption poverty. These basic human needs are usually listed in the material dimension as the need to be adequately nourished, the need to be decently clothed, the need to be reasonably sheltered, the need to escape avoidable diseases, the need to be (at least) minimally educated and the need to be mobile for purposes of social interaction and participation in economic activity.
\end{abstract}

Key words: Poverty, Status, Data Analysis, Conclusion.

\section{Introduction}

The Government's work should be to "listen to the poor, to work for the poor, and live for (the poor)", said Prime Minister Narendra Modi in his first speech in the $16^{\text {th }}$ Lok Sabha. This was just a day after President Pranab Mukherjee said in his address at the joint session of Parliament that "my Government will not be satisfied with mere 'poverty alleviation' and commits itself to the goal of 'poverty elimination'.

The mandate for Modi is being seen, above all, as a mandate for development; development which is inclusive and which leads to empowerment of the poor and downtrodden.

So, how has India done on poverty alleviation in the last few years? Are there regional differences in the pattern of poverty alleviation? Is rapid economic growth a prerequisite for poverty alleviation? Which States in India have been most successful at bringing people out of poverty?

An analysis by Swaniti Initative, a development consulting firm which works with legislators, found that between 2004-05 and 2011-12, most states did well at poverty alleviation. 19 out of the 28 States managed a reduction in poverty by 10 percentage points or more. In other words, 19 states managed to pull out more than $10 \%$ of their total population out of poverty. 12 of them achieved a reduction greater than 15 percentage points.

\section{The Curious Case of the North-East}

While the rest of the country was seeing a reduction in poverty, some of the north-east states actually saw a rise in poverty in this period. This is particularly surprising as most of these states had a significant rise in per capita income as shown below (Per-capita NDP for both years is at 2004-05 prices).

Table-I North-East States Per-capita NDP (Rs)

\begin{tabular}{|l|l|}
\hline Nagaland & 41,522 \\
\hline Mizoram & $39,253.7$ \\
\hline Meghalaya & 38,944 \\
\hline Arunachal Pradesh & 38,130 \\
\hline Assam & 22,956 \\
\hline Manipur & 24,327 \\
\hline Tripura & 40,411 \\
\hline
\end{tabular}


Table-2 North-East States Poverty HCR (\%)

\begin{tabular}{|l|l|}
\hline Tripura & 14.1 \\
\hline Nagaland & 18.9 \\
\hline Mizoram & 20.4 \\
\hline Meghalaya & 11.9 \\
\hline Arunachal Pradesh & 34.7 \\
\hline Assam & 32 \\
\hline Manipur & 36.9 \\
\hline Tripur & 14.1 \\
\hline & \\
\hline
\end{tabular}

Tripura is a notable exception that bucked this trend. It saw a massive increase in per-capita NDP in this period and a sharp decline in poverty rates. From having the highest burden of poverty in 2004-05, it had the $2^{\text {nd }}$ lowest poverty rate in 2011-12 among the seven north-east states.

\section{Rich States Have Done Better}

Is there a correlation between economic growth and poverty reduction? The table below analyses the performance of the seven richest states in terms of per-capita NDP in 2004-05.

Some of these rich States like Goa, Gujarat and Maharashtra had very high poverty rates. Others like Punjab, Haryana, Kerala and Himachal Pradesh had high per capita incomes as well as low poverty rates in 2004-05.

Table-3

\begin{tabular}{|c|c|c|c|}
\hline \multicolumn{4}{|l|}{ 2004-05 } \\
\hline States & Rank on & Poverty & Rank on \\
\hline & per-capita NDP & HCR (\%) & poverty reduction \\
\hline Goa & 1 & 25 & 9 \\
\hline Haryana & 2 & 24.1 & 8 \\
\hline Maharashtra & 3 & 38.1 & 21 \\
\hline Himachal Pradesh & 4 & 22.9 & 7 \\
\hline Punjab & 5 & 20.9 & 6 \\
\hline Gujarat & 6 & 31.8 & 14 \\
\hline Kerala & 7 & 19.7 & 5 \\
\hline \multicolumn{4}{|l|}{ 2011-12 } \\
\hline & Rank on & Poverty & Rank on \\
\hline & per-capita NDP & HCR (\%) & poverty reduction \\
\hline Goa & 1 & 5.1 & 1 \\
\hline Haryana & 3 & 11.2 & 8 \\
\hline Maharashtra & 2 & 17.4 & 15 \\
\hline Himachal Pradesh & 8 & 8.1 & 3 \\
\hline Punjab & 10 & 8.3 & 5 \\
\hline Gujarat & 4 & 16.6 & 14 \\
\hline Kerala & 7 & 7.1 & 2 \\
\hline
\end{tabular}

* All these states did much better in poverty reduction in the seven-year period between 2004 and 2011, a period in which they continued to grow at high rates.

*Goa now has the highest per-capita NDP and the lowest poverty rate. Himachal Pradesh, Kerala, Punjab and Maharashtra have also improved their rank on poverty HCR in 2011-12 over 2004-05.

* Gujarat, despite high economic growth, continues to have a sizeable proportion of its population below the poverty line.

Table-3

BIMAROU States - still a mountain to climb

\begin{tabular}{|c|c|c|c|c|}
\cline { 2 - 5 } \multicolumn{1}{c|}{} & \multicolumn{2}{c|}{$2004-05$} & \multicolumn{2}{c|}{$2011-12$} \\
\hline State & $\begin{array}{c}\text { Poverty } \\
\text { HCR } \\
(\%)\end{array}$ & $\begin{array}{c}\text { Rank on } \\
\text { poverty } \\
\text { reduction }\end{array}$ & $\begin{array}{c}\text { Poverty } \\
\text { HCR } \\
\text { (\%) }\end{array}$ & $\begin{array}{c}\text { Rank on } \\
\text { poverty } \\
\text { reduction }\end{array}$ \\
\hline Odisha & 57.2 & 28 & 32.6 & 23 \\
\hline Bihar & 54.4 & 27 & 33.7 & 24 \\
\hline Rajasthan & 34.4 & 18 & 14.7 & 13 \\
\hline $\begin{array}{c}\text { Madhya } \\
\text { Pradesh }\end{array}$ & 48.6 & 25 & 31.7 & 21 \\
\hline Uttar Pradesh & 40.9 & 23 & 29.4 & 20 \\
\hline
\end{tabular}

Source: http://jigyasa.swaniti.in/, Planning Commission 
The BIMAROU (Bihar, Madhya Pradesh, Rajasthan, Odisha, Uttar Pradesh) states are known for their poor socio-economic indicators, especially the extremely high poverty periods. Between 2004-05 and 2011-12, most of these States did considerably well in poverty alleviation (see table below). However, despite these achievements, they are still ranked pretty low in 2011-12, indicating the need to do much more to catch up with the rest of the country.

"There does seem to be a correlation between economic growth and poverty reduction in most States," said Rwitwika Bhattacharya, CEO of Swaniti. The top five growing states between 2004-05 and 2011-12 Sikkim, Uttarakhand, Bihar, Maharashtra and Tamil Nadu -saw an improvement in their poverty ranks in the period. However, states with relatively modest growth rates, such as Tripura, have also done remarkably well at lifting people out of poverty.

\section{Conclusion}

India is very conscious that all its dreams for national development will remain incomplete until weaker sections of the society also benefit from these developments. There have been arguments in favour and against the role of economic growth in poverty elevation. For example as early as 1997 some of the messages from the World Bank were that it is through rapid growth that India will be able to reduce poverty and generate resources to invest in the health and education of its people - who will in turn sustain this growth (Gaiha and Kulkarni 1998). As in 2008, the Government of India is committed to mainstreaming the marginalized in the process of economic growth. Education is one of the most important sectors in the Eleventh Five Year Plan to actualize this vision. For example, while SSA is to ensure universal coverage for the children of educationally backward sections as well as all other focus groups, "At the same time, all state plans to access SSA funds will be reviewed to ensure that minority children have equal space to participate in the state's school system. As SSA only covers children up to elementary (class VIII) level, measures will be undertaken to ensure that minority children have equal o quote once more from the Foreword to the Eleventh Five Year Plan by the Prime Minister of India "The higher rate of growth that we have set out for ourselves, coupled with our thrust on the growth process being inclusive, should ensure that the struggle for the removal of chronic poverty, ignorance, and disease will register major gains in the Eleventh Plan, I am confident that the Eleventh Plan will achieve its targets and objectives despite the challenges we face. This would be a major step in realizing our vision of a prosperous, inclusive, happy, and caring India where all citizens reap the benefits of economic development and feel empowered.

\section{References}

[1]. Raja J. Chelliah and R. Sudarshan. Income-Poverty and Beyond. Anthem Press, London, UK 1999.

[2]. Ratnakar Gedam. Poverty in India. Deep \& Deep Publications, New Delhi. 1995

[3]. Rohini Nayyar. Rural Poverty in India. Oxford Unviersity Press, Bombay 1991

[4]. S.M Dahiwale. Rural Poverty and Slums. Rawat Publications, Jaipur and New Delhi. 1997

[5]. Poverty in India Since 1974. Nathan Associates, Inc. 2002

[6]. Asian Development Bank. www.adb.org

[7]. Ahluwalia, Montek S (2000): 'Economic Performance of States in Post-Reforms Period', Economic and Political Weekly, May 611

[8]. Banerjee, Abhijit and T. Piketty (2003): 'Top Indian Incomes, 1956-2000', BREAD Working

[9]. Paper No.46, available at http://www.ksg.harvard.edu/cid/bread/046.htm Bhalla, Surjit S (2003): 'Recounting the Poor: Poverty in India, 1983-99', Economic and Political Weekly , January25-31

[10]. Datt, Gaurav, Valerie Kozel, Martin Ravallion (2003): ‘A Model-Based Assessment of India’s Progress in Reducing Poverty in the 1990s', Economic and Political Weekly,January25-31. 